\title{
Schwann Cells But Not Olfactory Ensheathing Cells Inhibit CNS Myelination via the Secretion of Connective Tissue Growth Factor
}

\author{
Rebecca Lamond and Susan C. Barnett \\ Institute of Infection, Immunity and Inflammation, University of Glasgow, Glasgow G12 8TA, United Kingdom
}

Cell transplantation is a promising strategy to promote CNS repair and has been studied for several decades with a focus on glial cells. Promising candidates include Schwann cells (SCs) and olfactory ensheathing cells (OECs). Both cell types are thought to be neural crest derived and share many properties in common, although OECs appear to be a better candidate for transplantation by evoking less astrogliosis. Using CNS mixed myelinating rat cultures plated on to a monolayer of astrocytes, we demonstrated that SCs, but not OECs, secrete a heat labile factor(s) that inhibits oligodendrocyte myelination. Comparative qRT-PCR and ELISA showed that SCs expressed higher levels of mRNA and protein for connective tissue growth factor (CTGF) than OECs. Anti-CTGF reversed the SCM-mediated effects on myelination. Both SCM and CTGF inhibited the differentiation of purified rat oligodendrocyte precursor cells (OPCs). Furthermore, pretreatment of astrocyte monolayers with SCM inhibited CNS myelination and led to transcriptional changes in the astrocyte, corresponding to upregulation of bone morphogenic protein $4 \mathrm{mRNA}$ and CTGF mRNA (inhibitors of OPC differentiation) and the downregulation of insulin-like growth factor $2 \mathrm{mRNA}$ (promoter of OPC differentiation). CTGF pretreatment of astrocytes increased their expression of CTGF, suggesting that this inhibitory factor can be positively regulated in astrocytes. These data provide evidence for the advantages of using OECs, and not mature SCs, for transplant-mediated repair and provide more evidence that they are a distinct and unique glial cell type.

\section{Introduction}

Disease or injury to the CNS results in a series of detrimental effects, including loss of tissue, irreversible damage of neurons and their demyelination, as well as the formation of a glial scar, which presents a physical and molecular barrier to repair (Silver and Miller, 2004). Many strategies have been studied to promote neurite outgrowth and remyelination, including cell transplantation and pharmacological intervention to counteract inhibitory signals.

A range of neural cells have been proposed as candidates for transplant-mediated repair of the CNS. We have focused on glial cells, making comparison between Schwann cells (SCs) and olfactory ensheathing cells (OECs). OECs have been studied because of their ability to support continual neurogenesis within the olfactory system while guiding regenerating fibers to their targets in the olfactory bulbs (Graziadei et al., 1978, Graziadei and Graziadei, 1979; Farbman, 1990). Furthermore, OECs have been demonstrated to enhance the regeneration of DRGs, which suc-

\footnotetext{
Received July 30, 2013; revised 0ct. 21, 2013; accepted 0ct. 24, 2013.

Author contributions:S.C.B. designed research; R.L. performed research; R.L. analyzed data; R.L. and S.C.B. wrote the paper.

R.L. was supported by a Lord Kelvin/Adam Smith PhD scholarship.

The authors declare no competing financial interests.

Correspondence should be addressed to Dr. Susan C. Barnett, Institute of Infection, Immunity and Inflammation,

Sir Graeme Davies Building, Room B329, 120 University Place, University of Glasgow, Glasgow G12 8TA, United Kingdom. E-mail: Susan.Barnett@Glasgow.ac.uk.

DOI:10.1523/JNEUROSCI.3233-13.2013

Copyright $\odot 2013$ the authors $\quad 0270-6474 / 13 / 3318686-12 \$ 15.00 / 0$
}

cessfully transcend the glia limitans to reenter the CNS (RamónCueto and Nieto-Sampedro, 1994) in addition to enhancing axonal regeneration in several models of spinal cord injury (SCI) (Li et al., 1998; Ramón-Cueto et al., 1998; Richter et al., 2005; Andrews and Stelzner, 2007; Toft et al., 2007). SCs have also shown promise after transplantation for SCI (Kuhlengel et al., 1990; Paíno et al., 1993; Raisman et al., 1993; Zujovic et al., 2012). Both OECs (Franklin et al., 1996; Barnett et al., 2000; Sasaki et al., 2004) and SCs (Gilmore, 1971; Blakemore and Crang, 1985; Baron-Van Evercooren et al., 1997) myelinate CNS axons with peripheral type myelin after transplantation.

However, much controversy surrounds which cell type would be most beneficial for transplant-mediated repair of the CNS. One possible caveat of using SCs is that they form boundaries with astrocytes and exacerbate astrogliosis, whereas OECs integrate well with host glia and do not cause reactive gliosis (Lakatos et al., 2000, 2003; Ramer et al., 2004; Fairless et al., 2005 SantosSilva et al., 2007; Afshari et al., 2010a,b; Higginson et al., 2012). Although both cells types differ in their interactions with astrocytes, relatively little is known regarding whether or not they affect the myelinating capability of host oligodendrocytes. Because remyelination is an important consideration for maximizing functional recovery after CNS injury/disease (Bartzokis, 2012), identifying possible key differences in candidate cells for transplantation could be beneficial for developing clinically relevant therapies for CNS repair.

Recently, it was shown that the astrocyte-reactive phenotype influenced myelination in culture and microarray analysis of 
these astrocytes identified candidates, which reduced myelination. These included CXCL10 and connective tissue growth factor (CTGF/CCN2) (Nash et al., 2011). Exogenous CTGF has been demonstrated to block the excessive differentiation of oligodendrocytes in vitro and in vivo (Stritt et al., 2009), further suggesting its role as a possible negative regulator of oligodendrocyte myelination. Previous work from our laboratory demonstrated the necessity of an astrocyte monolayer for supporting myelination and long-term survival of neurons in our established culture system (Sorensen et al., 2008). Using these same cultures, we have shown in the current study that SCs, but not OECs, inhibit CNS myelination in vitro via secretion of CTGF. Furthermore, although we have shown that CTGF reduces the differentiation of purified oligodendrocytes in the absence of other CNS cells, we also demonstrated that factors secreted by SCs reduce CNS myelination via astrocyte-dependent effects. Thus, despite their antigenic and morphological similarities, OECs and SCs differ significantly in important aspects of CNS repair.

\section{Materials and Methods}

Astrocyte monolayers. Confluent monolayers of astrocytes were differentiated from neurospheres derived from the striata of postnatal day 1 (P1) Sprague Dawley rat pups of both sexes, as previously described ( $>95 \%$ positive) (Sorensen et al., 2008; Nash et al., 2011). To produce monolayers of astrocytes, spheres were gently triturated and placed into DMEM containing $10 \%$ FBS and plated down onto poly-L-lysine $(13 \mu \mathrm{g} / \mathrm{ml}$, Sigma) coated $13 \mathrm{~mm}$ glass coverslips (VWR International) in 24-well plates (Corning). Astrocyte monolayers were grown to confluency, and myelinating cultures were plated directly on top of the astrocytes or the astrocyte monolayers were taken for analysis or treated with experimental growth factors (GFs) and then analyzed using PCR, Western blotting, or immunocytochemistry.

OECs. OECs were isolated from the olfactory bulbs of postnatal day 7 (P7) Sprague Dawley male and female rat pups as previously described using a DIY EasySep kit and the p75 ${ }^{\text {NTR }}$ antibody (Franceschini and Barnett, 1996; modified in Higginson and Barnett, 2011) (Stem Cell Technologies) Purified OECs were maintained in DMEM low glucose (Invitrogen) containing 5\% (v/v) FBS (Invitrogen) fibroblast growth factor 2 (FGF2, $25 \mathrm{ng} / \mathrm{ml}$; PeproTech), forskolin $\left(5 \times 10^{-7} \mathrm{M}\right.$, Sigma), heregulin ( $\mathrm{Hrg} \beta 1,50 \mathrm{ng} / \mathrm{ml}$; R\&D Systems), and astrocyte-conditioned medium (ACM, 1:5), which was collected from a confluent $T 75 \mathrm{~cm}^{2}$ flask of astrocytes after $48 \mathrm{~h}$ in serum free media (Alexander et al., 2002). OECs were added directly to myelinating cultures, to generate condition medium, or prepared as lysates for further analysis.

Schwann cell (SC) preparation. SCs were generated from the sciatic nerve of P7 Sprague Dawley rat pups (male and female) and purified using cytosine arabinoside $\left(10^{-5} \mathrm{M}\right.$, Sigma $)$ and a complement kill using anti-Thy1.1 (1:50 supernatant, Sigma), followed by the addition of rabbit complement (1:4, Harlan Laboratories) as previously described (Lakatos et al., 2000). Purified SCs were maintained in 10\% FBS supplemented with ( $\operatorname{Hrg} \beta 1,20 \mathrm{ng} / \mathrm{ml}$; R\&D Systems) and forskolin $\left(10^{-6} \mathrm{M}\right)$.

Myelinating cultures. These were prepared as previously described (Sorensen et al., 2008; Nash et al., 2011). The myelinating cultures were generated from the spinal cords of embryonic day 15.5 rat pups by enzymatic dissociation and plated on a monolayer of neurosphere-derived astrocytes. The mixed culture $(150,000$ cells/100 $\mu \mathrm{l})$ were maintained in high-glucose DMEM supplemented with $0.5 \mathrm{mg} / \mathrm{ml}$ insulin, 50 nм hydrocortisone, $10 \mathrm{ng} / \mathrm{ml}$ biotin, and a mixture of hormones, including 1 $\mathrm{mg} / \mathrm{ml}$ apotransferrin, $6 \mu \mathrm{M}$ selenium, $20 \mathrm{~mm}$ putrescine, and $4 \mu \mathrm{M}$ progesterone (differentiation media, $\mathrm{DM}^{+}$). After $12 \mathrm{~d}$ in culture, the insulin was removed from the media $\left(\mathrm{DM}^{-}\right)$to encourage the differentiation of oligodendrocyte precursor cells. For the addition of exogenous glial cells to the cultures, cell suspensions of OECs or SCs were added to the plating media containing the dissociated embryonic cells before plating on to astrocyte monolayers.

Collecting conditioned media (CM) from purified cells. To assess the effects of secreted factors derived from OECs and SCs on myelinating
CNS cells, CM was collected from purified monolayers of each cell type. Cells were grown to confluency in a T25 $\mathrm{cm}^{2}$ flask, and fresh media was added to each flask $(3 \mathrm{ml})$, collected after $72 \mathrm{~h}$, and filtered sterile $(0.22$ $\mu \mathrm{m}$ filter, Sartorius Stedim). CM was collected in media specific for each cell type/cultures being investigated and from cells, which were around passage 3 (i.e., DMEM-10\% FBS for treating astrocytes, DM for treating myelinating cultures). CM experimental treatment involved either a 1:4 or a 1:8 dilution with fresh media. In some experiments, SC conditioned medium (SCM) was heat treated at $55^{\circ} \mathrm{C}$ for $1 \mathrm{~h}$ to assess whether the factor was a protein. Heat-treated SCM (h.SCM) was then diluted as before with fresh DM and added to the cultures every other day from day 12 .

Treatment of myelinating cultures. In some experimental paradigms, myelinating cultures were treated with CTGF ( $11 \mathrm{kDa}$ human recombinant protein, PeproTech) every other feeding day from day 12 at a concentration of $10 \mathrm{ng} / \mathrm{ml}$, which was added to fresh DM. A neutralizing antibody to CTGF (mouse monoclonal; R\&D Systems) was used at a concentration of $10 \mathrm{ng} / \mathrm{ml}$ and added directly to SCM or directly to DM for control, and then added to the cultures from day 12 onwards. Astrocyte monolayers (before the myelinating cultures being plated on top) were treated by (1) conditioned media from coverslips of SCs placed directly in the same Petri dish, (2) addition of diluted SCM for $4 \mathrm{~d}$, or (3) incubation with $10 \mathrm{ng} / \mathrm{ml}$ CTGF. Thereafter, pretreated astrocytes and their supernatants were retained for qRT-PCR and ELISA studies or rinsed in PBS and used as normal as a monolayer for myelinating cultures.

Oligodendrocyte precursor cell (OPC) cultures. OPCs were generated by shaking off from monolayers of cortical-derived astrocytes from P1 rats as described by Noble and Murray (1984). Briefly, the cortices were dissected and enzymatically digested. Cells were triturated, spun and resuspended in DMEM-10\% FBS, and cultured for 10-14 d in a poly-Llysine-coated flask. Top-dwelling OPCs were shaken off flasks and placed in a $90 \mathrm{~mm}$ Petri dish for $20 \mathrm{~min}$ (McCarthy and de Vellis, 1980). The shaken-off supernatant was removed from the Petri dish (leaving behind the attached microglia), spun down, and the OPCs resuspended in DMEM-BS (defined serum-free medium modified from Bottenstein and Sato, 1979) containing $0.5 \mathrm{mg} / \mathrm{ml}$ insulin, $10 \mathrm{~mm}$ human transferrin, 100 mu glutamine, and $100 \mathrm{mg} / \mathrm{ml}$ gentamycin (all Sigma), supplemented with the GFs, FGF2 $(10 \mu \mathrm{g} / \mathrm{ml})$, and platelet-derived growth factor (2 $\mu \mathrm{g} / \mathrm{ml}$; PeproTech), and plated onto poly-L-lysine-coated coverslips (Raff et al., 1983; Bögler et al., 1990). The cells were maintained in DMEM-BS plus GFs for 5-7 d to promote proliferation. After this time, FGF2 and platelet-derived growth factor could be removed and replaced with DMEM-BS alone (to promote differentiation into oligodendrocytes), SCM, OCM (collected in DMEM-BS), or CTGF (10 ng/ml) diluted in DMEM-BS every other day for $7 \mathrm{~d}$. Controls included retaining some OPCs in GFs, to maintain the progenitor population.

Immunocytochemistry and antibodies. Neurites were visualized using an antibody against phosphorylated neurofilament (SMI-31, anti-mouse IgG1, 1:1500; Covance), whereas mature myelin was visualized using the AA3 antibody (1:100, anti-rat) (Yamamura et al., 1991), which labels proteolipid protein (PLP)/DM20. Caspr (contactin-associated protein) was used to stain paranodes (Abcam, IgG1, $5 \mu \mathrm{g} / \mathrm{ml}$ ) after methanol fixing. The $\mathrm{O} 4$ antibody (1:1 hybridoma, anti-mouse IgM) (Sommer and Schachner, 1981) and an antibody against NG2 (1:200 mIgG1, Millipore) were used to define purified OPCs and to assess their differentiation status. For surface labeling, primary antibodies (diluted in DMEM) were applied and left for 20-30 min at room temperature, washed, and the isotype-specific secondary antibody (1:100, Invitrogen) added for a further 20-30 min. Finally, cells were fixed in 4\% PFA for $15 \mathrm{~min}$, washed in PBS, and $\mathrm{ddH}_{2} \mathrm{O}$, and then mounted in Vectashield (Vector Laboratories) containing DAPI to visualize nuclei. For intracellular antigens, cells were fixed in $4 \%$ PFA for $15 \mathrm{~min}$, permeabilized with $0.05 \%$ Triton X-100 for a further $15 \mathrm{~min}$, and then blocked using blocking buffer (containing PBS with $0.1 \%$ Triton X-100, $0.2 \%$ gelatin). Primary antibodies were added to the cultures for $1-2 \mathrm{~h}$ at room temperature or overnight at $4^{\circ} \mathrm{C}$, followed by washing and then incubation with the corresponding secondary antibody for $45 \mathrm{~min}$ at room temperature. Coverslips were washed and mounted as described before. 
Imaging and quantification. Cells were imaged using an Olympus BX51 fluorescent microscope, and images were captured using Image-Pro software. Quantitative analysis of neurite density and myelination has been described previously in detail (Sorensen et al., 2008). Briefly, 10 images from each coverslip were taken at random at $10 \times$ magnification (duplicate/experiment and $n$ of at least 3). Images were opened in Image (NIH systems, version 1.45) or Adobe Photoshop Elements 7.0 for further analysis to determine neurite density, the percentage of myelinated axons, or to calculate cell numbers and their expression of markers of interest. Neurite density was calculated as the percentage of pixels of SMI-31/total pixels. To only quantify myelin sheaths and not immature and mature oligodendrocytes, Adobe Photoshop was used to edit images of myelinating cultures. Myelin sheaths were manually drawn over using a pure blue brush size 9 paint tool. A custom-made macro, which recognizes the pixel value of where the blue (manually drawn sheaths) overlaps with the green channel (PLP staining), was then run on all images. These values were expressed as a percentage of the total SMI-31 reactivity to give a value for percentage myelinated axons, which were standardized to control levels of myelination, denoted throughout this study as myelin arbitrary units (Sorensen et al., 2008; Nash et al., 2011).

Quantification of oligodendrocyte markers. Immunocytochemistry was performed 1 and $5 \mathrm{~d}$ after treatment of purified OPCs, using anti-NG2 and the $\mathrm{O} 4$ antibody. Their differentiation stage was based upon the number of cells expressing each of these markers, coupled with a brief descriptive of their morphology. Total cell number was calculated by counting DAPI nuclei using the ImageJ cell counter. The number of cells that did not express oligodendrocyte markers (contaminating astrocytes or microglia in OPC preps or astrocytes, neurons, or microglia in myelinating cultures) was then subtracted from this value to give an approximation of the total DAPI count for the OPC/oligodendrocyte population.

RNA extraction. RNA was extracted from purified cultures of OECs and SCs or from pretreated astrocytes using a PureLink RNA Mini-Kit (Ambion/Invitrogen) according to the manufacturer's protocol. The integrity and quality of the RNA were assessed using a Bioanalyzer 6000 Nano LabChip platform, and the RNA was retained for qRT-PCR studies. The synthesis of genomic DNA was minimized by using a Precision DNase kit (Primer Design).

$q R T-P C R$. cDNA was synthesized from RNA using a reverse transcription kit (Primer Design; RT-nanoscript) according to the manufacturer's instructions. The reaction was prepared in a 96 well plate using a 7900HT Fast Real-Time PCR System with SDS 2.3 software (Applied Bioscience). Mastermix containing SYBR Green, was used to quantify mRNA expression (Precision-SY, Primer Design). The software was set up to include four distinct phases of thermocycling ranging from $60^{\circ} \mathrm{C}$ to $95^{\circ} \mathrm{C}$. An average of the three triplicate wells for each sample was taken and any outliers, whereby the $\mathrm{C}_{\mathrm{T}}$ values differed by more than one cycle, were removed. Values of 35 cycles or above were considered to represent little or no mRNA expression. $\mathrm{C}_{\mathrm{T}}$ values were expressed relative to the housekeeping gene GAPDH using the comparative $\mathrm{C}_{\mathrm{T}}$ method (Livak and Schmittgen, 2001) to describe data in terms of a relative quantification of fold change (RQ value), normalized to control expression. Forward and reverse primers for connective tissue growth factor (CTGF/CCN2), bone morphogenic protein 4 (BMP4) and insulin growth factor 2 (IGF2) were bought from Primer Design and validated for use in rat cultures.

ELISA. To assess the levels of CNTF or CTGF in CM from SCs, OECs, and astrocytes, ELISA kits were used according to the manufacturer's instructions (CNTF DuoSet ELISA Kit, RayBiotech; CTGF standard protein detection kit, PeproTech). The standards and samples were added to the wells in triplicate, and the plate was read using a spectrophotometer (Dynex Technologies; MRX 2.02) and Revelation software (version 4.25) to determine the optical density of each well. Media was collected from confluent flasks of OECs, SCs, and astrocytes, and cells were counted from each flask so that data could be normalized to give a concentration per 100,000,000 cells. Supernatants were collected in the same media for all cell types within an experiment. In some cases, astrocytes were pretreated (PT) with SCM or CTGF for $4 \mathrm{~d}$, followed by removal of all media and then rinsed 3 times in PBS for a total of 15 min before fresh DMEMFBS was added for a further $24 \mathrm{~h}$ to be collected as CM.
Western blotting. After $4 \mathrm{~d}$ of treatment with SCM, astrocyte monolayers were washed with PBS and lysed using CelLytic M Cell Lysis Reagent (Sigma). The cells were then scraped off the coverslip, spun, and total protein concentration for each sample measured using the Nanodrop (Invitrogen). A total of 5-10 $\mu \mathrm{g}$ of protein was loaded into a NuPage $4-12 \%$ Bis-Tris Gel (Invitrogen) alongside rainbow molecular weight markers (GE Healthcare). The gel was run, transferred using the iBlot system (Invitrogen), and placed into PBST $(0.1 \%)$ containing 5\% dried milk (Marvel) for $2 \mathrm{~h}$ at room temperature. Anti-GFAP (polyclonal rabbit; Dako) was diluted in the blocking agent and added to the membrane for $1 \mathrm{~h}$ followed by anti-rabbit HRP-conjugated secondary antibody (anti-rabbit, 1:10,000, Santa Cruz Biotechnology) for $1 \mathrm{~h}$ at room temperature. The membrane was developed using an enhanced chemiluminescence kit (ECL plus, GE Healthcare). Optical densitometry was calculated using ImageJ, which attributed a pixel value to each band. Expression was then given as a ratio of the densitometry of each band relative to the densitometry of the GAPDH loading control for each condition.

Statistical analysis. For comparisons between groups of conditions, data were analyzed using paired Student's $t$ test in Microsoft Excel, with 1 as the null hypothesis of the mean. All values were expressed as mean \pm SEM. Significance was represented using $p$ values where values 0.05 were considered significant and were indicated by the presence of an asterisk. Two asterisks indicated results that were termed "highly significant" $(p<0.01)$. For myelinating cultures, the percentage of myelinated neurites was expressed as a ratio of the control to give myelin arbitrary units, where the control value was assigned 1 .

\section{Results}

\section{Exogenously added OECs, but not SCs, enhance} oligodendrocyte myelination

To assess the effects of exogenously added OECs or SCs on oligodendrocyte myelination in vitro, either 5000 or 10,000 purified OECs or SCs were added into the mixed embryonic spinal cord cell suspension and plated directly on top of an astrocyte monolayer from day 0 (Fig. 1). Control cultures did not contain exogenous OECs or SCs. After $26 \mathrm{~d}$ in culture, the level of myelination as assessed by PLP immunoreactivity was significantly higher after the addition of 10,000 OECs (Fig. $1 B$ ) compared with control cultures (Fig. 1A) or myelinating cultures containing 5000 OECs (Fig. $1 F)(n=3, p=0.04$ and $p=0.03$, respectively). Although there appeared to be a slight decrease in the level of myelination observed with the addition of 5000 OECs compared with control, this trend was not significant $(p>0.05)$. Conversely, the addition of SCs to the myelinating cultures reduced the level of myelination detected after $26 \mathrm{~d}$. Although myelination was not completely abolished under these conditions, the addition of 5000 SCs or 10,000 SCs significantly reduced the level of myelination compared with controls (Fig. $1 C)(n=3, p<0.01)$. The percentage of myelinated fibers observed in cultures containing 10,000 exogenous SCs versus cultures where 5000 SCs were added was also significantly lower $(p=0.04)$. Neurite density remained consistent with no significant change between conditions, at $\sim 75 \%$ (data not shown). OECs and SCs survived throughout the culture period, as evidenced by $\mathrm{p} 75^{\mathrm{NTR}}$ immunoreactivity, typical of both cell types, which was absent from control cultures However, the presence of $\mathrm{p} 75^{\mathrm{NTR}}$ did not colocalize with PLP in the myelin sheaths (Fig. $1 D, E$ ). Although the addition of a combination of both OECs and SCs to the embryonic spinal mix limited the survival of the cultures, labeling with an antibody against myelin protein zero (MPZ/P0) demonstrated its punctuate expression in OEC/SC-like cells (Fig. $1 H$ ), although it remained absent from the myelin sheath or from control cultures, suggesting a lack of peripheral myelin (Fig. 1G). 

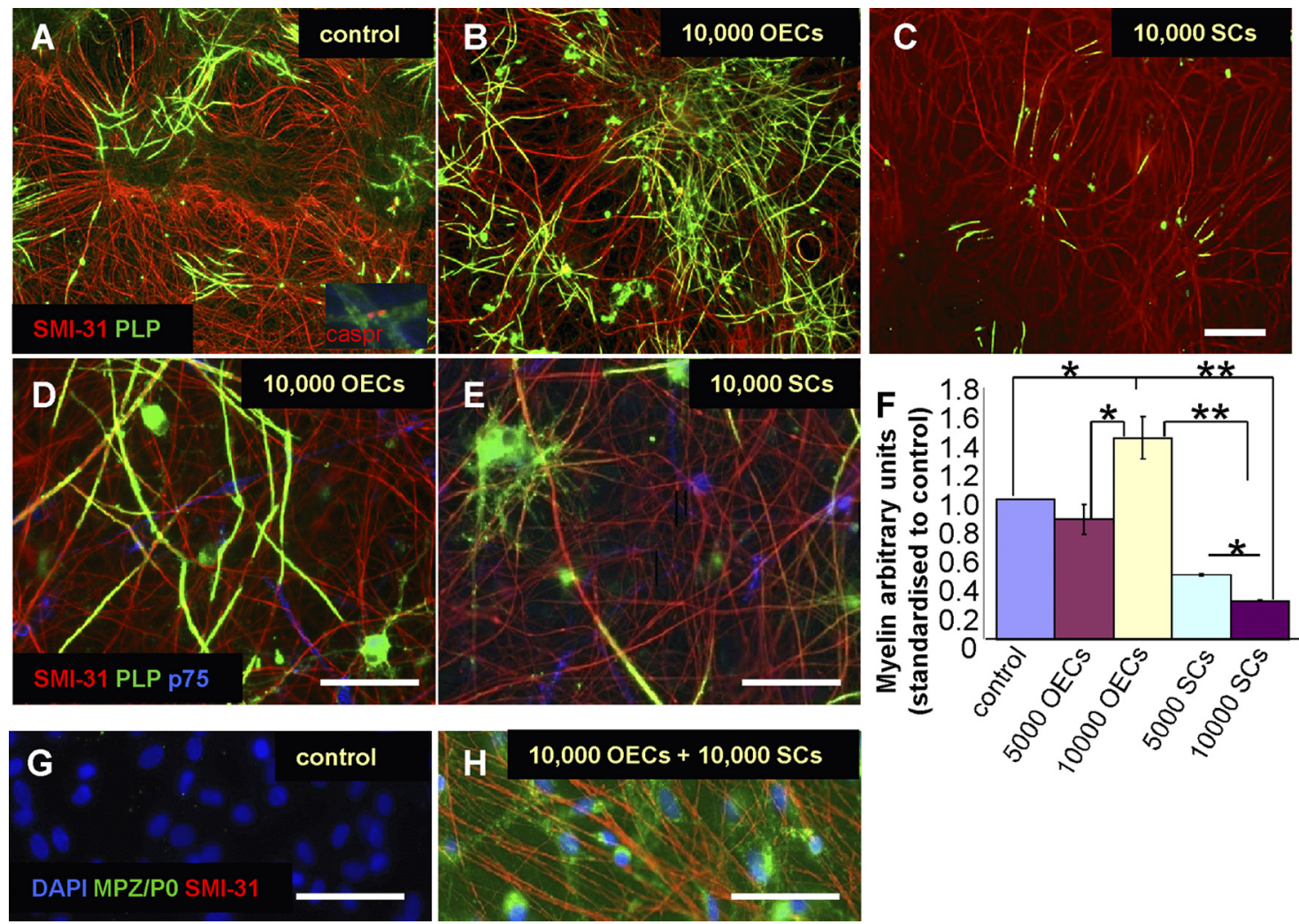

Figure 1. $0 E C S$, but not SCs, significantly enhanced the level of myelination in culture. A total of 5000 or $10,0000 E C s$ or SCs were added to myelinating cultures. After $26 \mathrm{~d}$, the level of myelination in control cultures $(\boldsymbol{A}, \boldsymbol{F})$ or cultures where $50000 \mathrm{ECS}$ had been added $(\boldsymbol{F})$ was significantly less than that of cultures containing $10,0000 \mathrm{ECS}(\boldsymbol{B}, \boldsymbol{F})$. A slight reduction (nonsignificant) in the level of myelination was seen between control cultures and cultures with 5000 exogenous $0 E C$. Conversely, the addition of 5000 or $10,000 S C s(C, F)$ significantly reduced the level of myelination compared with controls or OEC-containing cultures. $\mathrm{EECS}(\boldsymbol{D})$ and SCS $(\boldsymbol{E})$ were present at the end stage of culture but did not appear to associate with the myelin sheaths. In cultures containing both $S C S$ and OECS, the peripheral myelin protein zero (MPZ/PO) was evidenced in the cell bodies of OEC/SC-like cells but absent from the myelin sheaths $(\boldsymbol{H})$ and in control cultures where no exogenous cells were added (G). $\boldsymbol{A}$, Inset, caspr staining. SMI-31 labeled neurites, anti-PLP labeled mature myelin, and anti-p75 ${ }^{\mathrm{NTR}}$ labeled OECs and SCs. Scale bars, 100 and $50 \mu \mathrm{m} . n=3 .{ }^{*} p<0.05 .{ }^{* *} p<0.01$.

\section{SC effects on endogenous myelination were mediated by secreted factor(s)}

To investigate whether or not the SC-mediated effects on endogenous myelination were contact dependent or due to secreted factors, conditioned media (CM) was collected in differentiation media (DM) from comparable confluent flasks of both SCs (SCM) and OECs (OCM) and added to myelinating cultures 3 times weekly from day 12 onwards at a dilution of 1:8 in DM. Control cultures were maintained in DM. After $26 \mathrm{~d}$ in vitro, there was a significant reduction in myelination in cultures treated with SCM (Fig. 2B,F) versus untreated controls (Fig. $2 A, F)(n=3$, $p=0.03$ ). Furthermore, the addition of OCM did not significantly affect the level of myelination compared with untreated controls (Fig. 2C,F) $(n=3, p>0.05)$, although it did result in a significantly higher level of myelination compared with cultures treated with SCM $(n=3, p=0.04)$. To further investigate the nature of the SC-secreted factors, SCM was heat treated and added to the cultures. Heat-treated SCM (h.SCM) abrogated the negative effect on myelination compared with SCM treatment alone (Fig. $2 D, F)(n=4, p<0.01)$. Although this increase appeared to supersede the amount of myelin observed in control cultures, this was not statistically significant $(p>0.05)$. Neurite density was unaffected by all treatments (Fig. 2E).

\section{Reduction in myelination levels after SC/SCM addition to} cultures was not due to demyelination

To determine whether the SC-mediated decrease in oligodendrocyte myelination was the result of demyelination of myelinated fibers or the inhibition of the endogenous myelinating capacity of the cultures, myelinating cultures were allowed to develop as normal until day 26, and then SCM was added everyday for $4 \mathrm{~d}$. Untreated cultures were stained at both day 26 and day 30 . Results demonstrated that the addition of SCM to established (myelinated) cultures did not affect myelination (Fig. 2G). By day 30, there was a slight increase in the level of myelination in both untreated and SCM-treated cultures versus day 26 untreated cultures (Fig. $2 G$ ), although this increase was not significant $(n=3, p>0.05)$. Neurite density was unaffected (remained at $75-80 \%$ ). These data suggest that SCM prevents the formation of myelin as opposed to causing demyelination to occur in established CNS cultures.

\section{SCs and OECs express comparable levels of the} promyelinating factor CNTF, but SCs express significantly more of the myelin-inhibitory factor, CTGF, than OECs CTGF has recently emerged as a possible negative regulator of oligodendrocyte myelination (Stritt et al., 2009; Nash et al., 2011), whereas CNTF has been well documented for its role in enhancing oligodendrocyte differentiation and myelination (Stankoff et al., 2002; Cao et al., 2010; Nash et al., 2011). To determine whether there was a difference in the expression of CTGF mRNA between OECs and SCs, RNA was extracted from three biological replicates of comparably confluent cultures and compared by qRT-PCR (Fig. 3A). Supernatant was also collected from confluent flasks of OECs and SCs and from coverslips of Ns-astrocytes (ACM) to determine CTGF (Fig. 3B) and CNTF protein levels using commercial ELISA kits (Fig. 3C). In addition, 

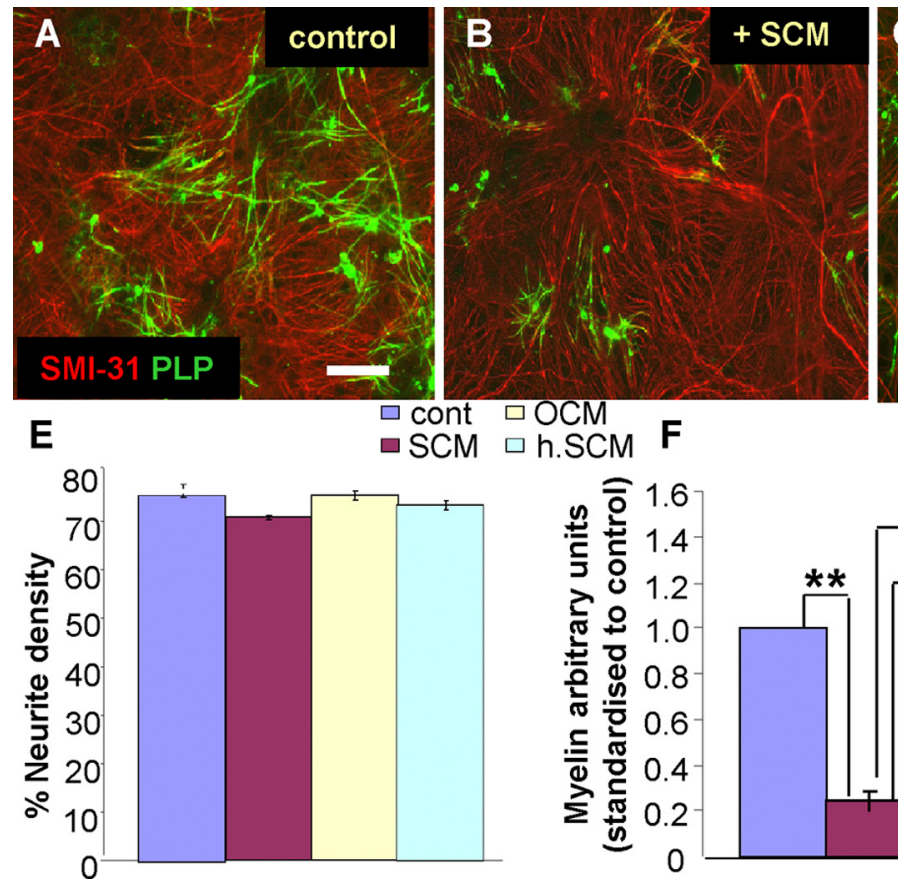
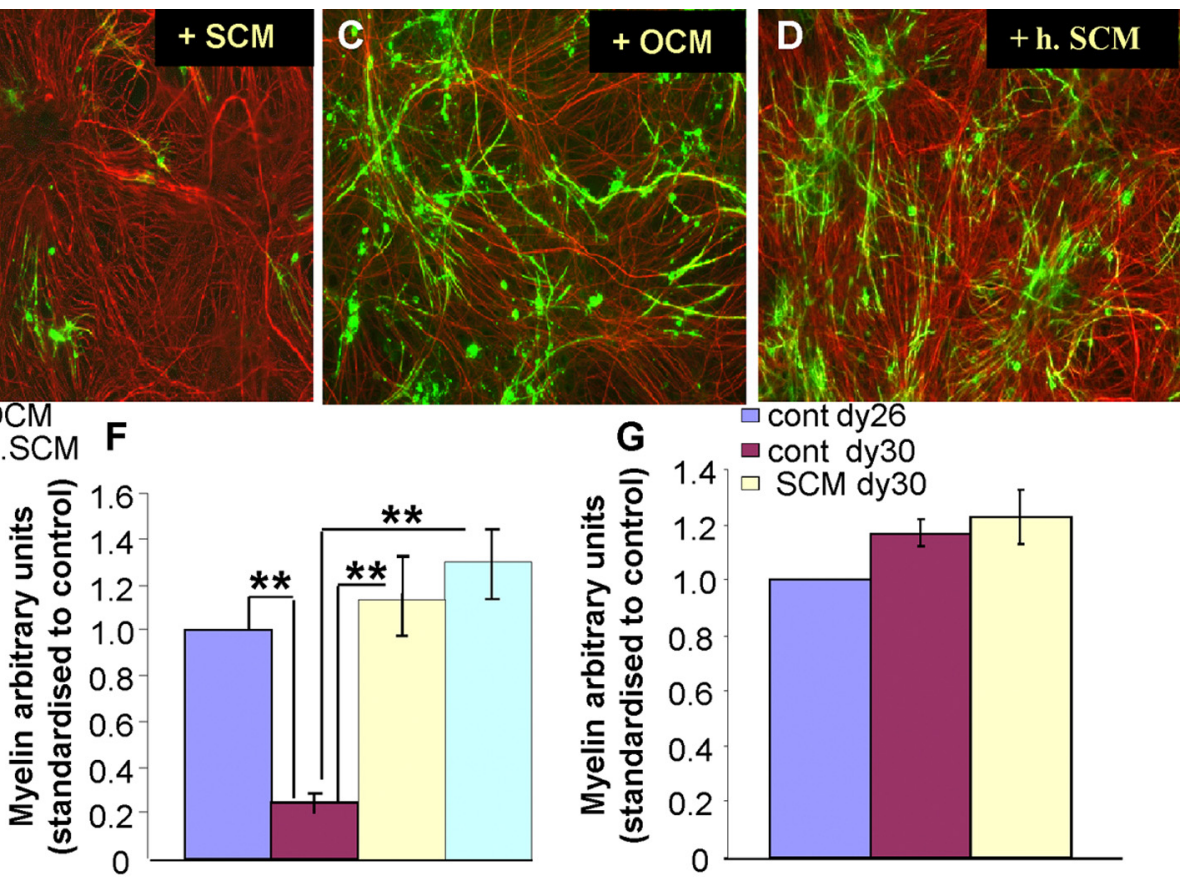

Figure 2. SCM, but not $0 C M$, significantly reduced the level of myelination compared with control cultures. $S C M$ or $O C M$ was added to myelinating cultures. After $26 \mathrm{~d}$, the level of myelination after SCM treatment $(\boldsymbol{B}, \boldsymbol{F})$ was significantly lower compared with controls $(\boldsymbol{A}, \boldsymbol{F})$. The addition of OCM to cultures $(\boldsymbol{C})$ did not significantly affect myelination compared with controls. Heat treatment of the SCM (h.SCM; $\boldsymbol{D})$ reversed the SCM-mediated inhibition of myelination. Neurite density was not affected by treatment $(\boldsymbol{E})$. The late addition of SCM to already myelinated cultures did not cause demyelination (G). Scale bars, $100 \mu \mathrm{m}$. Myelin sheaths and oligodendrocytes were labeled with an anti-PLP and SMI-31 labeled neurites. $n=4 .{ }^{* *} p<0.01$.
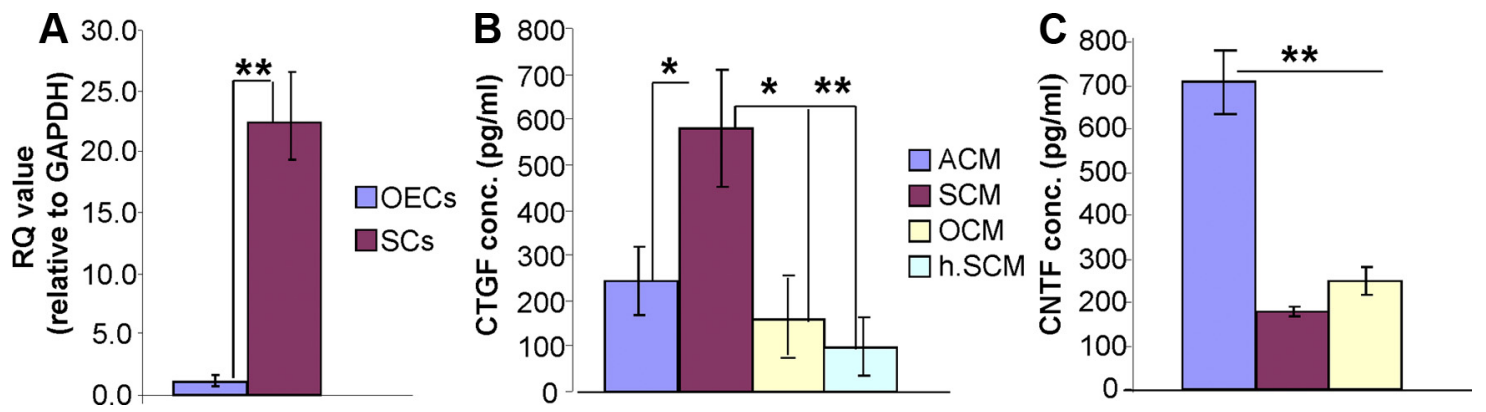

Figure 3. The expression of CNTF, and CTGF in SCS and OECS. A, qRT-PCR analysis of purified SCS and OECs demonstrated the significant upregulation of CTGF mRNA in SCS compared with OECS. $B$, ELISA demonstrated greater levels of CTGF in SCM compared with OCM and ACM and heat-treated SCM (h.SCM). There was no significant difference in secreted levels of CTGF comparing ACM, OCM, and h.SCM. C, ACM contained the greatest amount of the promyelinating factor CNTF, compared with OCM or SCM. There were no significant differences in CNTF levels in SCM versus 0 CM. ${ }^{*} p<0.05$. ${ }^{* *} p<0.01 . n=3$ biological replicates for qRT-PCR; $n=4$ batches of CM for ELISA.

h.SCM was also analyzed to assess the amount of CTGF that could still be detected after heat treatment. SCs expressed $\sim 20$ times more CTGF mRNA than OECs (Fig. $3 A)(n=3, p<0.01)$. SCM contained $\sim 500 \mathrm{pg} / \mathrm{ml}$ of CTGF assessed by ELISA (Fig. $3 B$ ), which was $\sim 3$ times ( $p=0.02$ ) greater than that secreted by OECs. Also, SCM contained significantly more CTGF than ACM $(p=0.03)$. h.SCM contained significantly less detectable CTGF than SCM, suggesting that heat treatment was sufficient to denature SC-secreted CTGF $(p<0.01)(n=4$ throughout $)$. Although ACM appeared to contain more CTGF than OCM and h.SCM, this was not significant. The expression of CNTF, however, was significantly greater in ACM, whereas SCM and OCM contained comparable levels (Fig. $3 C)(n=4, p<0.01)$.

\section{The addition of CTGF significantly reduced the level of} myelination in vitro

A human recombinant CTGF peptide containing only the $\mathrm{C}$ terminus of the molecule was added to the myelinating cultures from day
12 onwards to assess its effects on oligodendrocyte myelination (Fig. 4). The addition of CTGF significantly reduced the level of myelination compared with untreated cultures, although many $\mathrm{PLP}^{+}$oligodendrocytes not contacting axons were detected (Fig. $4 B, E, F)(n=$ $3, p<0.01$ ). Neurite density was not significantly affected by the addition of CTGF (Fig. 4A). To confirm that SCM contained CTGF, a neutralizing antibody to CTGF was added to SCM before its addition to the cultures. Conditions also included untreated cultures, SCM treatment without antibody, and antibody alone. SCM significantly reduced the level of myelination compared with control cultures (Fig. $4 D)(n=4, p<0.01)$ whereas anti- $(\alpha)$-CTGF added to SCM significantly increased the level of myelination compared with SCM treatment (Fig. $4 D, G)(n=3, p<0.01)$, although this increase was not significantly greater than the level of myelination in controls $(p>0.05)$. Treatment with the antibody alone did not significantly affect the level of myelination compared with controls $(p>0.05)$. Neurite density was not affected by the addition of the neutralizing antibody to CTGF (Fig. 4C). 
A

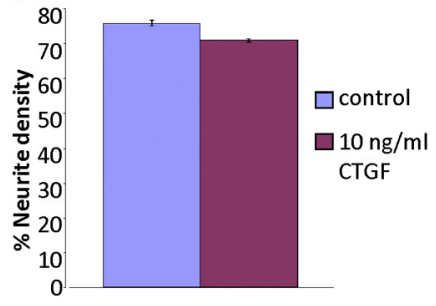

C

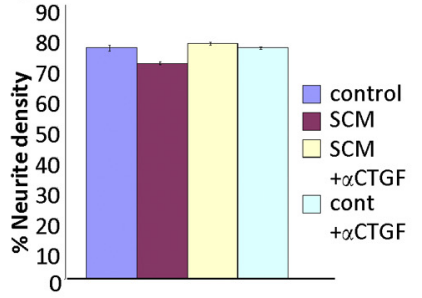

B

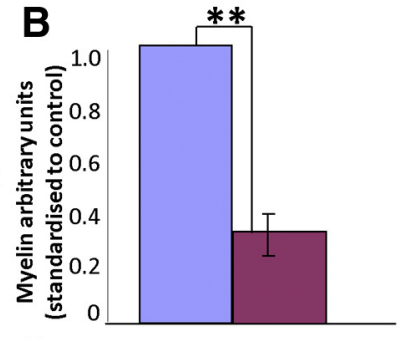

D

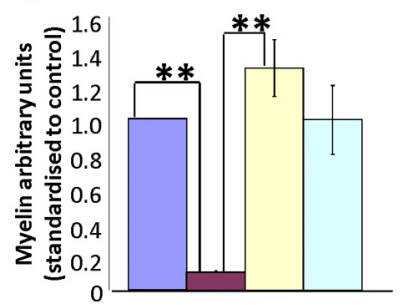

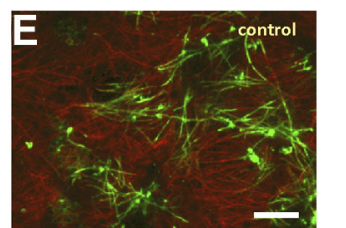
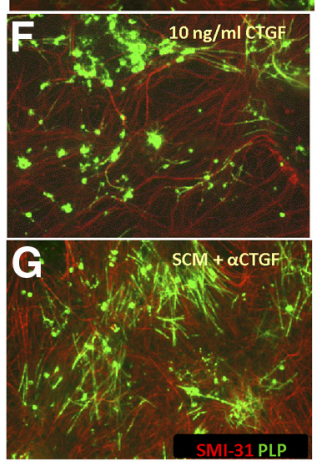

Figure 4. The inhibition of oligodendrocyte myelination in SCM can be reversed by anti-CTGF. CTGF peptide (10 ng/ml) was added to the cultures every other day from day 12 . After $26 \mathrm{~d}$ in culture, myelination was significantly reduced in CTGF-treated cultures $(\boldsymbol{B}, \boldsymbol{F})$, compared with controls $(\boldsymbol{B}, \boldsymbol{E})$. $\boldsymbol{A}$, Neurite density was not significantly affected by CTGF treatment. Anti-CTGF significantly restored the level of myelination versus treatment with $\operatorname{SCM}(\boldsymbol{D}, \boldsymbol{G})$. However, although this increase appeared to exceed the level of myelination observed in controls, this trend was not significant. The addition of the antibody alone to DM did not significantly alter myelination compared with controls, although this was significantly greater than that seen after SCM treatment (D). Neurite density was not significantly affected by treatment (C). SMI-31 labeled neurites; anti-PLP was used to detect oligodendrocytes and myelin sheaths. Scale bar, $100 \mu \mathrm{m} . n=3 .{ }^{*} p<0.05 .{ }^{* *} p<0.01$.
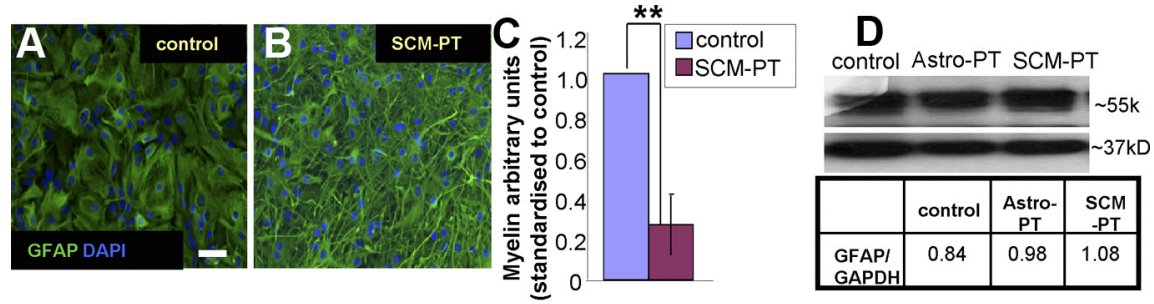

E 6
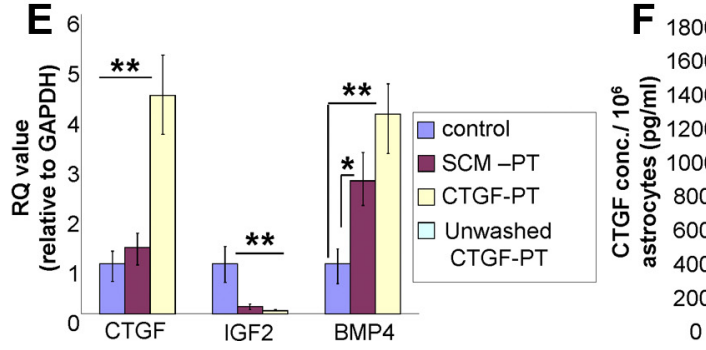

myelinating cultures in a $22-28 \mathrm{~d}$ assay. Sister astrocyte monolayers were retained at this point for qRT-PCR or Western blot analysis or pretreated with SCM or CTGF for subsequent ELISA studies. Immunolabeling of SCM-pretreated astrocytes (for $4 \mathrm{~d}$ ) demonstrated a marked difference in the morphology of treated versus untreated monolayers (Fig. $5 A, B$ ). Whereas untreated astrocytes displayed a flatter morphology, those that had been exposed to SC factors had a more protoplasmic appearance, typical of reactive gliosis. Furthermore, myelination was significantly reduced in cultures where the astrocyte monolayer had been pretreated by SCs (Fig. $5 C)(n=3, p<$ $0.01)$. Optical densitometry of Western blots detecting GFAP protein, however, indicated that its expression in astrocyte monolayers was not significantly altered by SCM pretreatment (Fig. $5 D)(n=3, p>$ 0.05). Both SCM and CTGF pretreatment of monolayers resulted in significant transcriptional changes in the astrocytes (Fig. $5 E$ ). The expression of bone morphogentic protein 4 (BMP4) mRNA was significantly increased in astrocytes after SCM or CTGF pretreatment $(n=3, p=0.02$ and $p<0.01$, respectively), but IGF2 mRNA was significantly decreased in astrocytes after either form of pretreatment versus untreated controls $(n=3, p<0.01)$. Pretreatment of astrocytes only with exogenous CTGF peptide, however, resulted in significant increases in the level of CTGF mRNA expressed by astrocytes, compared with untreated or SCM-treated astrocytes $(n=3$, $p<0.01)$. These findings were further validated by ELISA, which demonstrated that pretreating astrocytes for $4 \mathrm{~d}$ with CTGF peptide resulted in significant increases in the levels of CTGF protein detected in astrocyte supernatants, versus untreated or SCM-pretreated astrocytes (Fig. $5 F)(n=4$, $p<0.01)$. To ensure that these results were not due to exogenously added CTGF remaining in the astrocyte supernatant despite the washing steps, we tested for levels of CTGF in the supernatant of pretreated astrocytes not washed 3 times with PBS (unwashed CTGF-PT) (Fig. 5F). Failing to rinse the CTGF-treated astrocyte monolayers in PBS resulted in a significant increase in the detectable levels of CTGF protein in the astrocyte supernatant, compared with untreated astrocyte controls as well as SCMpretreated and CTGF-pretreated astrocytes,

Pretreatment of astrocyte monolayers with SCM or CTGF reduced the level of myelination in culture while inducing transcriptional changes in the astrocyte

Astrocyte monolayers were pretreated (PT) with SCM (SCM-PT) or CTGF (CTGF-PT) everyday for $4 \mathrm{~d}$. After this time, they were rinsed 3 times in PBS and then used as a typical monolayer support for which were washed in PBS $(n=4, p<0.01)$. Although it cannot be proven definitively that the CTGF detected by ELISA was secreted by the astrocytes as opposed to being leftover recombinant CTGF not washed out by the PBS, these results demonstrate that rinsing, at least to some extent, limits this effect and may correlate with the increase 


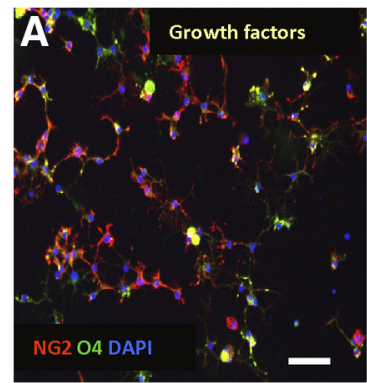

E

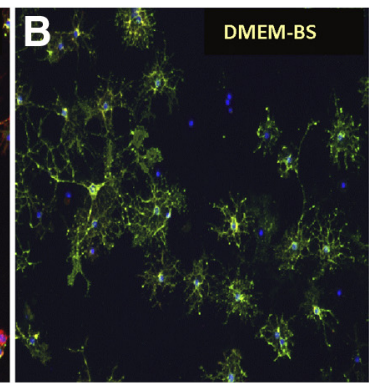
$\square$ growth factors
$\square$ DMEM-BS $\square$ DMEM-BS + SCM

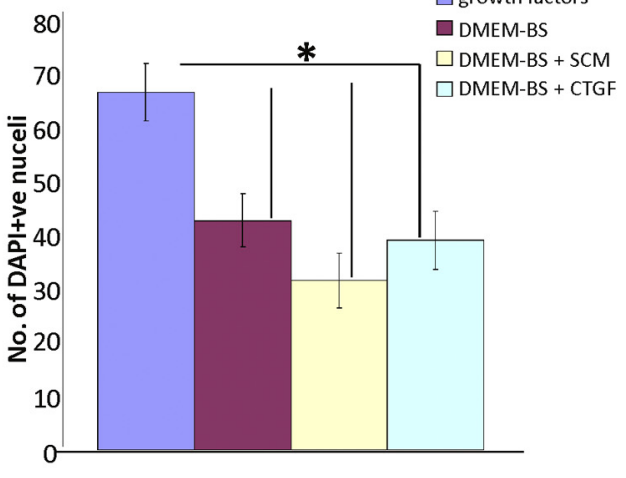

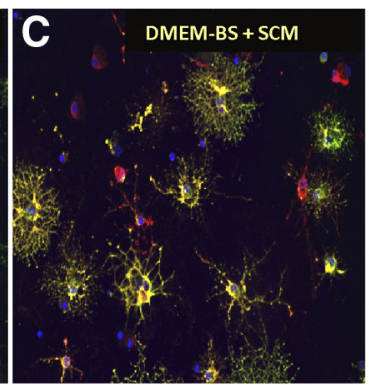

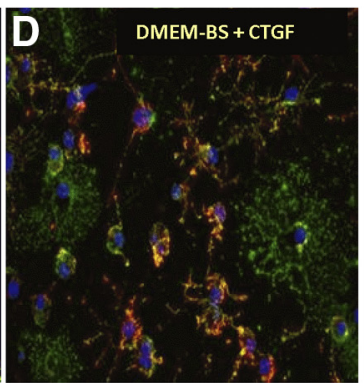

$\mathbf{F}$

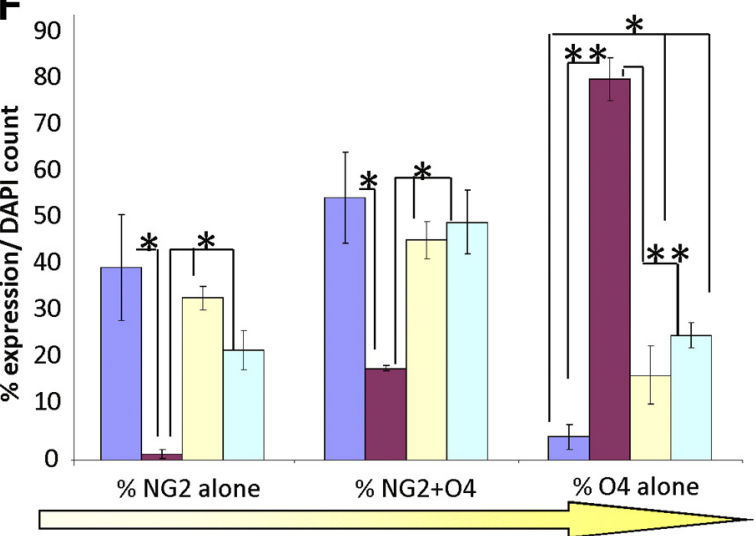

MATURATION

Figure 6. The expression of OPC differentiation markers is significantly reduced after treatment with SCM or CTGF. Purified OPCS were kept in GFs $(\boldsymbol{A})$ to retain their progenitor phenotype, whereas others were placed in DMEM-BS media $(\boldsymbol{B})$ to promote oligodendrocyte differentiation. SCM $(\boldsymbol{C})$ or $C$ TGF $(\boldsymbol{D})$ was added to cultures every other day for 7 d. $\boldsymbol{E}$, Graphical representation to show that as expected, GF promoted proliferation (A), whereas SCM, CTGF, or DMEM-BS had no effect. $\boldsymbol{F}$, Graphical representation of the effect of GFs, SCM, and CTGF on OPC differentiation. SCM or CTGF significantly reduced oligodendrocyte differentiation compared with DMEM-BS cultures to a similar extent, although SCM/CTGF-treated cells were more differentiated than those grown in GF conditions. Anti-NG2 labeled early lineage/progenitor cells; the 04 antibody labeled intermediate to mature oligodendrocytes. Scale bars, $50 \mu \mathrm{m} .{ }^{*} p<0.05 .{ }^{* *} p<0.01 . n=3$.

in mRNA for CTGF detected in the astrocytes pretreated with CTGF (Fig. 5E).

\section{Treatment of purified OPCs with SCM or CTGF inhibited their differentiation}

Purified cultures of OPCs were treated with SCM (collected in DMEM-BS) or CTGF $(10 \mathrm{ng} / \mathrm{ml})$ for $7 \mathrm{~d}$. Controls included retaining some OPCs in GFs, to maintain the progenitor population, or DMEM-BS to induce OPC differentiation into oligodendrocytes. After $7 \mathrm{~d}$, a significant increase in cell numbers was apparent after GF treatment, as assessed by counting DAPI ${ }^{+}$nuclei, compared with all other conditions (Fig. $6 E)(n=3, p<$ $0.05)$. There were no significant differences in the cell counts between the remaining treatments. The percentage of cells expressing NG2 alone in the absence of immunoreactivity of the $\mathrm{O} 4$ antibody (typical of an early lineage OPC) was significantly less in DMEM-BS (Fig. 6B, F), compared with GF controls (Fig. 6A, F) $(p=0.03)$ or treatment with SCM (Fig. 6C,F) $(p=0.02)$ or CTGF (Fig. $6 D, F)(p=0.03)$. The percentage of cells solely expressing NG2 after either SCM or CTGF treatment was not significantly altered compared with GF controls $(p>0.05)$. There was a significantly greater proportion of cells in the transient stages of differentiation (expressing both NG2 and positive for the O4 antibody) in GF conditions, compared with DMEM-BS controls $(p=0.02)$. Likewise, after treatment with SCM or CTGF, there were significantly more cells expressing both markers compared with DMEM-BS $(p=0.02)$ (Fig. $6 F$ ). The percentage of cells expressing both markers after treatment with SCM or CTGF compared with GF controls was not significantly different $(p>0.05)$. Approximately $80 \%$ of the cells maintained in DMEM-BS labeled with the $\mathrm{O} 4$ antibody in the absence of NG2 (suggesting a more differentiated phenotype), and this value was significantly greater than the percentage of cells labeled with the $\mathrm{O} 4$ antibody alone in GF controls $(p<0.01)$, and in $\operatorname{SCM}(p<0.01)$ or CTGF-treated cultures $(p=0.01)$. However, there was a significantly greater proportion of cells labeled with the $\mathrm{O} 4$ antibody in the absence of NG2 after treatment with SCM $(p=0.03)$ or CTGF $(p=0.04)$ compared with GF controls. When comparing SCM treatment with CTGF treatment, there were no significant differences across all cell profiles. Thus, treatment with SCM or CTGF resulted in significant shifts in marker expression, suggesting that, although these cells were more differentiated than those grown in GF, they were significantly less differentiated than OPCs, which were grown in DMEM-BS alone ( $n=3$ throughout).

A method of quantifying differentiation based upon characteristic morphology was also used to analyze data as a more sensitive means of assessing the stages of oligodendrocyte maturation (adapted from Huang et al., 2011). This method involved assessing the cell morphology as presimple, simple, complex, or membrane forming to describe the level of branching and differentiation (Fig. 7A). Values were given as percentage morphology of the total oligodendroglial population. Quantification using this method confirmed that the majority of cells in GF conditions retained a pre-simple morphology with little obvious process branching, typical of progenitor cells (Fig. $7 B$ ). This value was significantly higher than the percentage of cells displaying this morphology after incubation in DMEM-BS $(p<0.01)$ and SCM or CTGF treatment $(p=0.03)$. There was also a higher proportion of cells with pre-simple morphology after SCM or CTGF treatment compared with DMEM-BS alone $(p<0.01)$. Furthermore, the percentage of cells with a simple morphology (mostly primary 

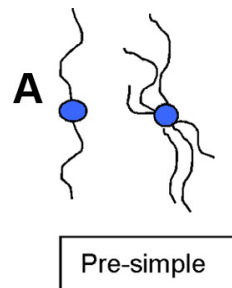
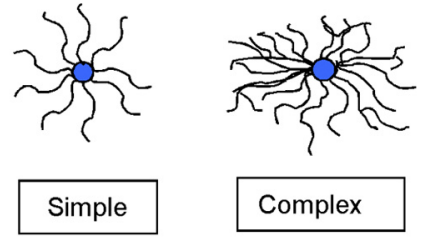

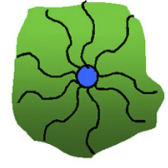

Membrane forming

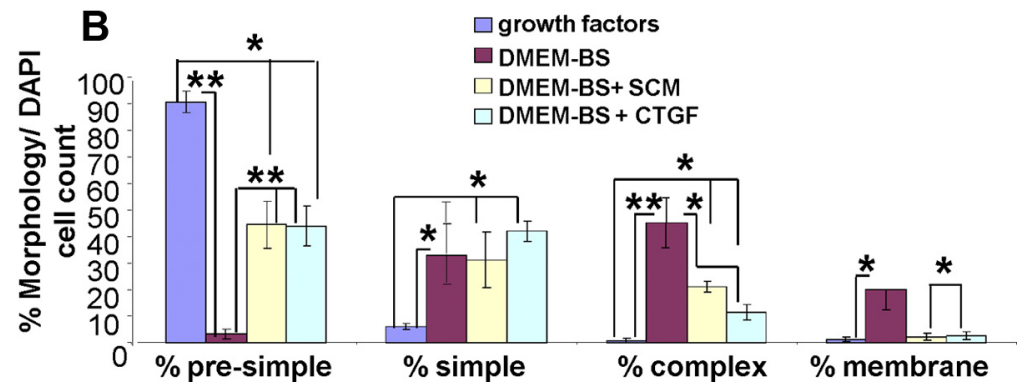

Figure 7. OPCS treated with SCM or CTGF were significantly less differentiated than those cultured in DMEM-BS, based upon morphological classification. Purified OPCs were kept in GFs DMEM-BS SCM or CTGF. Quantification was performed by assessing cells according to their morphology $(\boldsymbol{A})$ and expressed as a percentage over the total oligodendroglial cell count. "Presimple" described cells that were either bipolar or exhibited very little branching of their processes. The term "simple" was assigned to cells where there was evidence of moderate primary branching and the cells were no longer polarized. "Complex" described cells with extensive primary and secondary branching, whereas "membrane" was used to characterize cells that formed flat sheets of myelin membrane and were considered to be terminally differentiated. SCM or CTGF-treated OPCs were significantly less differentiated than those grown in DMEM-BS because the majority of these cells retained a presimple/simple morphology compared with the simple/complex phenotype exhibited by oligodendroglial cells in DMEM-BS (B). Approximately $90 \%$ of OPCs retained in GF exhibited a presimple morphology, making these cells significantly less differentiated than those grown in CTGF/SCM conditions. For all comparisons, there were no significant differences comparing SCM treatment with CTGF treatment. Anti-NG2 labeled early lineage/progenitor cells; the 04 antibody labeled intermediate to mature oligodendrocytes. ${ }^{*} p<0.05$. ${ }^{* *} p<0.01 . n=3$.

branching) was significantly higher in DMEM-BS $(p=0.04)$ and SCM or CTGF treatment ( $p=0.03, p=0.02$ ) compared with GF treatment. However, there was no significant difference in the percentage of cells displaying this morphology after either treatment (CTGF or SCM) versus DMEM-BS ( $p>0.05$ ). Virtually none of the cells grown in GF exhibited a complex (highly branched) morphology, and this value was highly significantly less than values obtained from DMEM-BS cultures $(p<0.01)$ and in SCM or CTGF-treated cultures ( $p=0.02$ and $p=0.04$, respectively). In addition, there were significantly fewer cells with complex morphologies after SCM or CTGF treatment compared with DMEM-BS conditions $(p=0.02)$. Finally, although myelin membrane formation was uncommon under all conditions, there was significantly more detected when OPCs were grown in DMEM-BS compared with GF, SCM, or CTGF treatment. There were no significant differences when comparing myelin membrane formation in treated cultures (SCM/CTGF) versus GF conditions ( $p>0.05)$.

\section{Discussion}

The use of glial cell transplants in the treatment of SCI is a strategy that holds great promise for repair of the damaged CNS. Clinical trials using autologous transplants of OECs and SCs as a regenerative strategy in spinal-injured patients have already begun (Féron et al., 2005; Lima et al., 2006, 2010; Mackay-Sim et al., 2008; Saberi et al., 2011; seealso http://www.miamiproject.miami.edu/page.aspx?pid= 1076). However, before this study, relatively little was known about the possible implications of transplanting either cell type on host oligodendrocyte behavior or how this could potentially impact upon patient recovery. Although some reports have suggested that OEC or SC remyelinated CNS fibers exhibit restored con- duction velocity (Felts and Smith, 1992; Honmou et al., 1996; Black et al., 2006), there is little evidence reporting on the long-term consequences of replacing central myelin with its structurally distinct peripheral counterpart.

\section{OECs, but not SCs, enhanced oligodendrocyte myelination in vitro} The addition of OECs to mixed neural cell cultures plated onto astrocyte monolayers enhanced oligodendrocyte myelination, whereas exogenous SCs significantly reduced it. Neither OECs nor SCs appeared to myelinate CNS axons in our myelinating cultures, as evidenced by a lack of P0 staining in the myelin sheaths, most likely resulting from the lack of ascorbic acid in our culture media (Eldridge et al., 1987). Our laboratory has previously shown that, when monolayers of OECs are allowed to condition a myelinating culture (two coverslips in the same Petri dish), myelination was significantly increased (Nash et al., 2011). In this paradigm, OECs were also exposed to factors being secreted by endogenous cells within the myelinating culture, as is also the case when OECs are exogenously added to the cultures. In the current study, the OEC-mediated enhancement of CNS myelination was not evidenced when using OCM collected from flasks of purified OECs, which had not been exposed to paracrine signaling from the myelinating cultures. On the other hand, SCs secrete a factor(s) that negatively affects oligodendrocyte myelination in culture, regardless of whether or not the SCs were exposed to paracrine signaling from endogenous CNS glia and neurons (data not shown).

It is unclear from this study which OEC secreted factors could be promoting myelination. From previous studies, CNTF has been shown to be a promyelinating factor (Stankoff et al., 2002; Nash et al., 2011); however, ELISA data demonstrated that purified OECs and SCs secrete comparable levels of CNTF. It is now evident that chemokines and their receptors play important roles, not only in recruitment of inflammatory cells and the initiation of immune-mediated demyelination but also in remyelination and repair of lesions (Robinson et al., 1998; Arnett et al., 2003; Omari et al., 2005; Kadi et al., 2006; Liu et al., 2010). Thus, a future microarray study could help to characterize the cytokine repertoire expressed by both OECs and SCs and their implications for the repair potential of both cell candidates.

\section{The SC-Induced Inhibition of CNS Myelination is Mediated via the Expression of CTGF}

Comparisons between purified OECs and SCs suggested that SCs expressed significantly higher levels of CTGF mRNA and protein than OECs. Furthermore, the neutralization of CTGF in SCM restored the level of myelination to control levels, whereas exogenous CTGF inhibited myelination. CTGF is a member of the $\mathrm{CCN}$ family of secreted matricellular proteins and can bind multiple ligands interacting with many other proteins to regulate cell function. Several CTGF receptors have been reported, but none is 


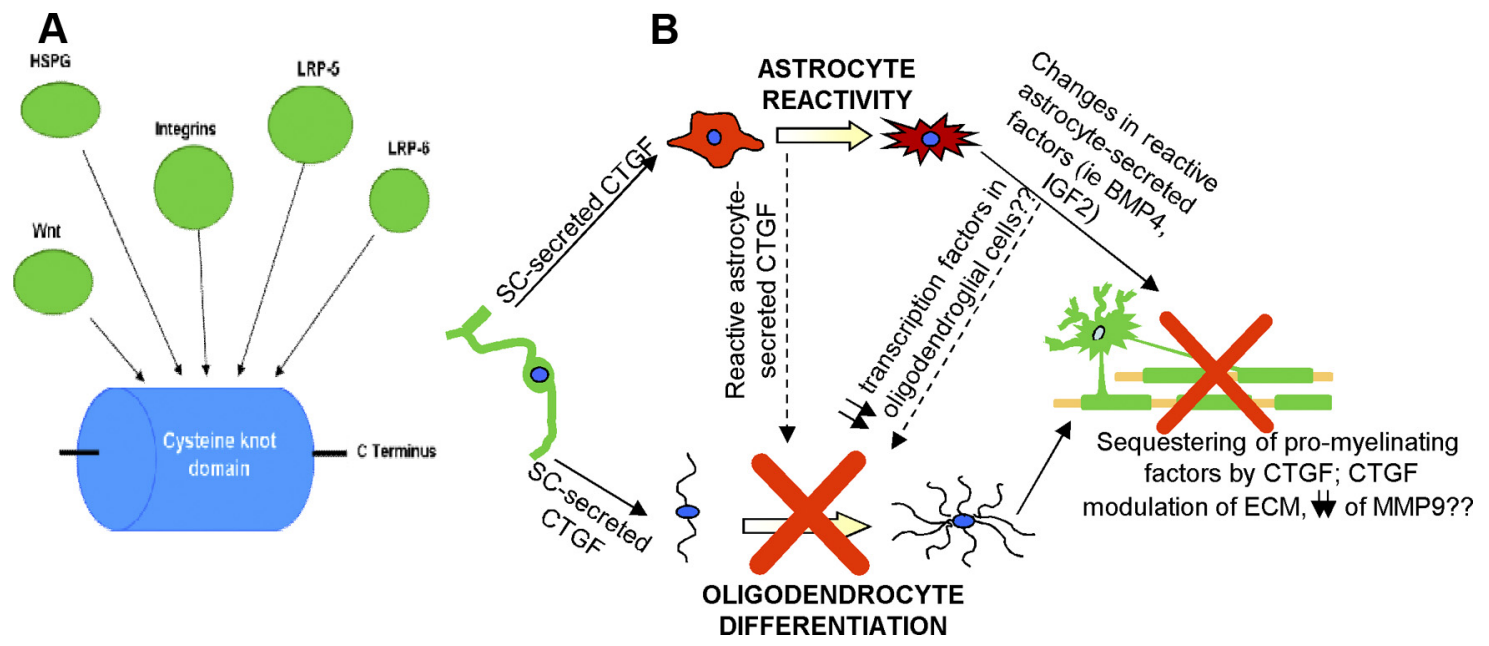

Figure 8. Hypothesized signaling mechanisms of CTGF. $A$, The11 kDa human recombinant CTGF peptide inhibited endogenous myelination in culture. This particular peptide contained only the C terminus and all of its binding domains. Unlike the full-length CTGF, it lacked, among other things, the IGF binding domain, said to underpin the previously published mechanisms by which CTGF inhibits oligodendrocyte maturation. B, Our results have shown that $S C M$, which contains $C T G F$, and/or CTGF alone significantly, reduced the differentiation of purified OPCs in culture. This direct inhibition of oligodendrocyte maturation could be the result of the sequestering of vital promyelinating factors by CTGF, or via the CTGF-induced modulation of the ECM, which is known to mediate aspects of process extension in oligodendrocytes. SC-secreted CTGF (and other possible factors) could also affect myelination indirectly, by enhancing astrocyte reactivity. Reactive astrocytes may alter their expression of mediators of myelination, such as BMP4 or IGF2, which in turn downregulate vital transcriptional factors in oligodendrocytes (i.e., 0lig1 and 0lig2). Furthermore, as reactive astrocytes are also a source of CTGF after injury, this could exacerbate the SC-induced block on oligodendrocyte differentiation by enhancing the bioavailability of CTGF at the lesion site. Because of the highly complex nature of the CTGF molecule, it is possible that CTGF affects myelination through multiple pathways. Furthermore, its signaling mechanisms are also likely to involve several unknown mediators of glial and neuronal cell behavior, culminating in this reduction in oligodendrocyte myelination.

unique for the cytokine (Mason, 2013). A previous study by Stritt et al. (2009) reported that CTGF negatively regulated oligodendrocyte myelination in vitro and in vivo, an effect that they postulated to be mediated via the sequestering of the promyelinating factor, insulin, by CTGF. However, our study has provided novel evidence to suggest that CTGF signaling may be more complicated than originally thought, given that our use of an $11 \mathrm{kDa}$ CTGF peptide lacking an IGF binding domain still resulted in a reduction in oligodendrocyte myelination in vitro (Fig. 8A). Although there is no denying the importance of IGF signaling on oligodendrocyte maturation (McMorris et al., 1986; Bartlett et al., 1991; Mozell and McMorris, 1991; Goddard et al., 1999) and the likelihood that its sequestration would impair this process, this study opens up the possibility that other mechanisms may also underpin the actions of the CTGF-mediated inhibition of myelination. For example, interactions with the ECM and integrins have been reported to affect oligodendrocyte differentiation (Frost et al., 1999; Colognato et al., 2002; Baron et al., 2003); thus, the presence of the integrin interacting site at the $\mathrm{C}$ terminus of CTGF could be involved in its dysregulation of myelination. Similarly, heparan sulfate proteoglycans affect the adhesion and polarization of oligodendrocytes, which precedes process extension and differentiation (Yim et al., 1993). Therefore, the interaction of oligodendrocyte heparan sulfate proteoglycans with the heparan sulfate proteoglycan binding domain of CTGF could conceivably alter oligodendrocyte behavior.

CTGF acts directly upon OPCs, as well as inducing transcriptional changes in astrocytes, to mediate its effects on myelination

CTGF treatment of purified OPCs inhibited their antigenic and morphological maturation in vitro. Furthermore, whereas Stritt et al. (2009) reported that astrocytes were not the target of CTGF, our data suggested that they may be involved, potentially via modulation of astrocyte-secreted factors, such as BMP4 (in- creased expression) or IGF2 (reduced expression). Previous reports have demonstrated that BMP4 inhibits oligodendrocyte differentiation and myelination (See et al., 2004; Sabo et al., 2011) and was upregulated by reactive astrocytes in a contusion model of SCI (Wang et al., 2011). It has been suggested that BMP4 could exert its effects on myelination by downregulating the transcription factors, Olig 1 and Olig2, which are required for oligodendrocyte differentiation (Cheng et al., 2007). The role of IGF2 in enhancing oligodendrocyte survival and differentiation is well documented (McMorris et al., 1986; Ye et al., 1995, 2002).

CTGF has been shown to be upregulated by reactive astrocytes in models of SCI in vivo, as well as in human patients with amyotrophic lateral sclerosis, where it is hypothesized to play a role in scar formation (Schwab et al., 2000; Spliet et al., 2003; Conrad et al., 2005). Whereas heparan sulfates, ephrins, FGF9, and $\mathrm{N}$-cadherin have previously been implicated in SC/astrocyte boundary formation and gliosis (Fairless et al., 2005; Santos-Silva et al., 2007; Afshari et al., 2010a; Higginson et al., 2012), SC-secreted CTGF could also be an important mediator in this process. Furthermore, by inducing astrocyte reactivity, SCs could actually drive the secretion of CTGF by astrocytes, thus exacerbating the nonpermissive environment arising after CNS injury via autocrine and paracrine signaling. Therefore, the possible mechanisms by which CTGF could negatively regulate endogenous CNS myelination are likely to be highly complicated and may involve multiple overlapping pathways, as summarized in Figure $8 \mathrm{~B}$. It is possible that a number of unidentified SC-related factors are also involved in negatively regulating oligodendrocyte myelination via astrocyte-dependent and independent mechanisms. Similarly, by neutralizing CTGF in SCM, other SC-secreted promyelinating factors may then be able to influence myelination. 


\section{Correlation of findings in vivo}

The majority of OEC or SC transplantation studies focus on reporting the ability of these exogenously added cells to myelinate CNS axons, as opposed to their effects on endogenous CNS myelination (Franklin et al., 1996; Barnett et al., 2000; Sasaki et al., 2004; Lankford et al., 2008) or endogenous SC myelination (Gilmore, 1971; Blakemore, 1975; Baron-Van Evercooren et al., 1997). However, early work has suggested that SC myelination overtakes endogenous myelination in the CNS in toxin-induced models of demyelination and that both central and peripherally myelinating glia are predominantly segregated by the presence of astrocytic end-feet (Blakemore, 1975; Blakemore and Patterson, 1975; Sims and Gilmore, 1983). Although these data do not prove that SCs are inhibitory to oligodendrocyte myelination in vivo, via the secretion of CTGF or other factors, they do suggest an interesting relationship between SCs and oligodendrocytes mediated by astrocytes, which may require further investigation in vivo. It has been shown that SCs can be modified to overexpress factors, such as BDNF and PSA-N-CAM, thus improving their integration within the glial scar and enhancing their repair potential after transplantation into a CNS lesion (Girard et al., 2005; Lavdas et al., 2006). Moreover, Schwann cells at immature stages of differentiation may overcome the negative effect on astrocytes documented by mature Schwann cells and hold therapeutic promise in the treatment of CNS pathologies. For example, skinderived precursors transplanted into the contused rat spinal cord were not only shown to promote a degree of locomotor recovery and remyelination after their differentiation into SCs, but they also demonstrated enhanced integration and reduced astrogliosis compared with transplants of differentiated SCs (Biernaskie et al., 2007). In addition, boundary cap cells have also been reported to differentiate into SCs with enhanced migratory abilities after their transplantation into the demyelinated rodent spinal cord (Woodhoo et al., 2007; Zujovic et al., 2010).

In conclusion, this study has provided novel evidence identifying key differences in SC and OEC properties, despite their similarity in origin from the neural crest (Barraud et al., 2010), which could be clinically relevant in a transplant scenario where remyelination is a key factor. Although SCs have many attractive growth-promoting attributes, these observations may be an important consideration for selecting the most appropriate cell candidate to promote the competent long-term functional repair of the damaged spinal cord. Thus, these findings could be interpreted as suggesting that OECs may be a more suitable candidate than unmodified mature SCs for cell-mediated repair strategies.

\section{References}

Afshari FT, Kwok JC, Fawcett JW (2010a) Astrocyte-produced ephrins inhibit Schwann cell migration via VAV2 signalling. J Neurosci 30:42464255. CrossRef Medline

Afshari FT, Kwok JC, White L, Fawcett JW (2010b) Schwann cell migration is integrin-dependent and inhibited by astrocyte-produced aggrecan. Glia 58:857-869. CrossRef Medline

Alexander CL, Fitzgerald UF, Barnett SC (2002) Identification of growth factors that promote long-term proliferation of olfactory ensheathing cells and modulate their antigenic phenotype. Glia 37:349-364. CrossRef Medline

Andrews MR, Stelzner DJ (2007) Evaluation of olfactory ensheathing and Schwann cells after implantation into a dorsal injury of adult rat spinal cord. J Neurotrauma 24:1773-1792. CrossRef Medline

Arnett HA, Wang Y, Matsushima GK, Suzuki K, Ting JP (2003) Functional genomic analysis of remyelination reveals importance of inflammation in oligodendrocyte regeneration. J Neurosci 23:9824-9832. Medline

Barnett SC, Alexander CL, Iwashita Y, Gilson JM, Crowther J, Clark L, Dunn LT, Papanastassiou V, Kennedy PG, Franklin RJ (2000) Identification of a human olfactory ensheathing cell that can effect transplant-mediated remyelination of demyelinated CNS axons. Brain 123:1581-1588. CrossRef Medline

Baron W, Decker L, Colognato H, ffrench-Constant C (2003) Regulation of integrin growth factor interactions in oligodendrocytes by lipid raft microdomains. Curr Biol 13:151-155. CrossRef Medline

Baron-Van Evercooren A, Avellana-Adalid V, Lachapelle F, Liblau R (1997) Schwann cell transplantation and myelin repair of the CNS. Mult Scler 3:157-161. CrossRef Medline

Barraud P, Seferiadis AA, Tyson LD, Zwart MF, Szabo-Rogers HL, Ruhrberg C, Liu KJ, Baker CV (2010) Neural crest origin of olfactory ensheathing glia. Proc Natl Acad Sci U S A 107:21040-21045. CrossRef Medline

Bartlett WP, Li XS, Williams M, Benkovic S (1991) Localization of insulinlike growth factor-1 mRNA in murine central nervous system during postnatal development. Dev Biol 147:239-250. CrossRef Medline

Bartzokis G (2012) Neuroglial pharmacology: myelination as a shared mechanism of action of psychotropic treatments. Neuropharmacology 7:2137-2153. CrossRef Medline

Biernaskie J, Sparling JS, Liu J, Shannon CP, Plemel JR, Xie Y, Miller FD, Tetzlaff W (2007) Skin-derived precursors generate myelinating Schwann cells that promote remyelination and functional recovery after contusion spinal cord injury. J Neurosci 27:9545-9559. CrossRef Medline

Black JA, Waxman SG, Smith KJ (2006) Remyelination of dorsal column axons by endogenous Schwann cells restores the normal pattern of Nav1.6 and Kv1.2 at nodes of Ranvier. Brain 129:1319-1329. CrossRef Medline

Blakemore WF (1975) Remyelination by Schwann cells of axons demyelinated by intraspinal injection of 6-aminonicotinamide in the rat. J Neurocytol 4:745-757. CrossRef Medline

Blakemore WF, Crang AJ (1985) The use of cultured autologous Schwann cells to remyelinate areas of persistent demyelination in the central nervous system. J Neurol Sci 70:207-223. CrossRef Medline

Blakemore WF, Patterson RC (1975) Observations on the interactions of Schwann cells and astrocytes following X-irradiation of neonatal rat spinal cord. J Neurocytol 4:573-585. CrossRef Medline

Bögler O, Wren D, Barnett SC, Land H, Noble M (1990) Cooperation between two growth factors promotes extended self-renewal and inhibits differentiation of oligodendrocyte type-2 astrocyte (O-2A) progenitor cells. Proc Natl Acad Sci U S A 87:6368-6372. CrossRef Medline

Bottenstein JE, Sato GH (1979) Growth of a rat neuroblastoma cell line in serum-free supplemented medium. Proc Natl Acad Sci U S A 76:514517. CrossRef Medline

Cao Q, He Q, Wang Y, Cheng X, Howard RM, Zhang Y, DeVries WH, Shields CB, Magnuson DS, Xu XM, Kim DH, Whittemore SR (2010) Transplantation of ciliary neurotrophic factor-expressing adult oligodendrocyte precursor cells promotes remyelination and functional recovery after spinal cord injury. J Neurosci 30:2989-3001. CrossRef Medline

Cheng X, Wang Y, He Q, Qiu M, Whittemore SR, Cao Q (2007) Bone morphogenetic protein signaling and olig1/2 interact to regulate the differentiation and maturation of adult oligodendrocyte precursor cells. Stem Cells 25:3204-3214. CrossRef Medline

Colognato H, Baron W, Avellana-Adalid V, Relvas JB, Baron-Van Evercooren A, Georges-Labouesse E, ffrench-Constant C (2002) CNS integrins switch growth factor signalling to promote target-dependent survival. Nat Cell Biol 4:833-841. CrossRef Medline

Conrad S, Schluesener HJ, Adibzahdeh M, Schwab JM (2005) Spinal cord injury induction of lesional expression of profibrotic and angiogenic connective tissue growth factor confined to reactive astrocytes, invading fibroblasts and endothelial cells. J Neurosurg Spine 3:319-326. Medline

Eldridge CF, Bunge MB, Bunge RP (1987) The role of basal lamina in Schwann-cell function. Anat Rec 218:A40. CrossRef

Fairless R, Frame MC, Barnett SC (2005) N-cadherin differentially determines Schwann cell and olfactory ensheathing cell adhesion and migration responses upon contact with astrocytes. Mol Cell Neurosci 28:253-263. CrossRef Medline

Farbman AI (1990) Olfactory neurogenesis: genetic or environmental controls? Trends Neurosci 13:362-365. CrossRef Medline

Felts PA, Smith KJ (1992) Conduction properties of central nerve fibers remyelinated by Schwann cells. Brain Res 574:178-192. CrossRef Medline

Féron F, Perry C, Cochrane J, Licina P, Nowitzke A, Urquhart S, Geraghty T, Mackay-Sim A (2005) Autologous olfactory ensheathing cell transplan- 
tation in human spinal cord injury. Brain 128:2951-2960. CrossRef Medline

Franceschini IA, Barnett SC (1996) Low-affinity NGF-receptor and E-NCAM expression define two types of olfactory nerve ensheathing cells that share a common lineage. Dev Biol 173:327-343. CrossRef Medline

Franklin RJ, Gilson JM, Franceschini IA, Barnett SC (1996) Schwann celllike myelination following transplantation of an olfactory bulbensheathing cell line into areas of demyelination in the adult CNS. Glia 17:217-224. CrossRef Medline

Frost EE, Buttery PC, Milner R, ffrench-Constant C (1999) Integrins mediate a neuronal survival signal for oligodendrocytes. Curr Biol 9:12511254. CrossRef Medline

Gilmore SA (1971) Autoradiographic studies of intramedullary Schwann cells in irradiated spinal cords of immature rats. Anat Rec 171:517-528. CrossRef Medline

Girard C, Bemelmans AP, Dufour N, Mallet J, Bachelin C, Nait-Oumesmar B, Baron-Van Evercooren A, Lachapelle F (2005) Grafts of brain-derived neurotrophic factor and neurotrophin 3-transduced primate Schwann cells lead to functional recovery of the demyelinated mouse spinal cord. J Neurosci 25:7924-7933. CrossRef Medline

Goddard DR, Berry M, Butt AM (1999) In vivo actions of fibroblast growth factor-2 and insulin-like growth factor-I on oligodendrocyte development and myelination in the central nervous system. J Neurosci Res 57: 74-85. CrossRef Medline

Graziadei GA, Graziadei PP (1979) Neurogenesis and neuron regeneration in the olfactory system of mammals: II. Degeneration and reconstitution of the olfactory sensory neurons after axotomy. J Neurocytol 8:197-213. CrossRef Medline

Graziadei PP, Levine RR, Graziadei GA (1978) Regeneration of olfactory axons and synapse formation in the forebrain after bulbectomy in neonatal mice. Proc Natl Acad Sci U S A 75:5230-5234. CrossRef Medline

Higginson JR, Barnett SC (2011) The culture of olfactory ensheathing cells (OECs), a distinct glial cell type. Exp Neurol 229:2-9. CrossRef Medline

Higginson JR, Thompson SM, Santos-Silva A, Guimond SE, Turnbull JE, Barnett SC (2012) Differential sulfation remodelling of heparan sulfate by extracellular 6-O-sulfatases regulates fibroblast growth factor-induced boundary formation by glial cells: implications for glial cell transplantation. J Neurosci 32:15902-15912. CrossRef Medline

Honmou O, Felts PA, Waxman SG, Kocsis JD (1996) Restoration of normal conduction properties in demyelinated spinal cord axons in the adult rat by transplantation of exogenous Schwann cells. J Neurosci 16:3199-3208. Medline

Huang JK, Jarjour AA, Nait Oumesmar B, Kerninon C, Williams A, Krezel W, Kagechika H, Bauer J, Zhao C, Baron-Van Evercooren A, Chambon P, ffrench-Constant C, Franklin RJ (2011) Retinoid X receptor gamma signaling accelerates CNS remyelination. Nat Neurosci 14:45-53. CrossRef Medline

Kadi L, Selvaraju R, de Lys P, Proudfoot AE, Wells TN, Boschert U (2006) Differential effects of chemokines on oligodendrocyte precursor proliferation and myelin formation in vitro. J Neuroimmunol 74:133-146. CrossRef Medline

Kuhlengel KR, Bunge MB, Bunge RP, Burton H (1990) Implantation of cultured sensory neurons and Schwann cells into lesioned neonatal rat spinal cord: II. Implant characteristics and examination of corticospinal tract growth. J Comp Neurol 293:74-91. CrossRef Medline

Lakatos A, Franklin RJ, Barnett SC (2000) Olfactory ensheathing cells and Schwann cells differ in their in vitro interactions with astrocytes. Glia 32:214-225. CrossRef Medline

Lakatos A, Barnett SC, Franklin RJ (2003) Olfactory ensheathing cells induce less host astrocyte response and chondroitin sulphate proteoglycan expression than Schwann cells following transplantation into adult CNS white matter. Exp Neurol 184:237-246. CrossRef Medline

Lankford KL, Sasaki M, Radtke C, Kocsis JD (2008) Olfactory ensheathing cells exhibit unique migratory, phagocytic, and myelinating properties in the X-irradiated spinal cord not shared by Schwann cells. Glia 56:16641678. CrossRef Medline

Lavdas AA, Franceschini I, Dubois-Dalcq M, Matsas R (2006) Schwann cells genetically engineered to express PSA show enhanced migratory potential without impairment of their myelinating ability in vitro. Glia 53:868878. CrossRef Medline

Li Y, Field PM, Raisman G (1998) Regeneration of adult rat corticospinal axons induced by transplanted olfactory ensheathing cells. J Neurosci 18:10514-10524. Medline

Lima C, Pratas-Vital J, Escada P, Hasse-Ferreira A, Capucho C, Peduzzi JD (2006) Olfactory mucosa autografts in human spinal cord injury: a pilot clinical study. J Spinal Cord Med 29:191-203; discussion 204-206. Medline

Lima C, Escada P, Pratas-Vital J, Branco C, Arcangeli CA, Lazzeri G, Maia CA, Capucho C, Hasse-Ferreira A, Peduzzi JD (2010) Olfactory mucosal autografts and rehabilitation for chronic traumatic spinal cord injury. Neurorehabil Neural Repair 24:10-22. CrossRef Medline

Liu L, Darnall L, Hu T, Choi K, Lane TE, Ransohoff RM (2010) Myelin repair is accelerated by inactivating CXCR2 on nonhematopoietic cells. J Neurosci 30:9074-9083. CrossRef Medline

Livak KJ, Schmittgen TD (2001) Analysis of relative gene expression data using real-time quantitative PCR and the 2(-delta delta $\mathrm{C}(\mathrm{T})$ ) Method. Methods 25:402-408. CrossRef Medline

Mackay-Sim A, Féron F, Cochrane J, Bassingthwaighte L, Bayliss C, Davies W, Fronek P, Gray C, Kerr G, Licina P, Nowitzke A, Perry C, Silburn PA, Urquhart S, Geraghty T (2008) Autologous olfactory ensheathing cell transplantation in human paraplegia: a 3-year clinical trial. Brain 131: 2376-2386. CrossRef Medline

Mason RM (2013) Fell-Muir lecture: connective tissue growth factor (CCN2), a pernicious and pleiotropic player in the development of kidney fibrosis. Int J Exp Pathol 94:1-16. CrossRef Medline

McCarthy KD, de Vellis J (1980) Preparation of separate astroglial and oligodendroglial cell cultures from rat cerebral tissue. J Cell Biol 85:890-902. CrossRef Medline

McMorris FA, Smith TM, DeSalvo S, Furlanetto RW (1986) Insulin-like growth factor I/somatomedin C: a potent inducer of oligodendrocyte development. Proc Natl Acad Sci U S A 83:822-826. CrossRef Medline

Mozell RL, McMorris FA (1991) Insulin-like growth factor I stimulates oligodendrocyte development and myelination in rat brain aggregate cultures. J Neurosci Res 30:382-390. CrossRef Medline

Nash B, Thomson CE, Linington C, Arthur AT, McClure JD, McBride MW, Barnett SC (2011) Functional duality of astrocytes in myelination. J Neurosci 31:13028-13038. CrossRef Medline

Noble M, Murray K (1984) Purified astrocytes promote the in vitro division of a bipotential glial progenitor cell. EMBO J 3:2243-2247. Medline

Omari KM, John G, Lango R, Raine CS (2005) Role for CXCR2 and CXCL1 on glia in multiple sclerosis. Glia 53:24-31. CrossRef Medline

Paíno CL, Fernandez-Valle C, Bates ML, Bunge MB (1993) Regrowth of axons in lesioned adult rat spinal cord: promotion by implants of cultured Schwann cells. J Neurocytol 1994 23:433-452. Medline

Raff MC, Miller RH, Noble M (1983) A glial progenitor cell that develops in vitro into an astrocyte or an oligodendrocyte depending on culture medium. Nature 303:390-396. CrossRef Medline

Raisman G, Lawrence JM, Brook GA (1993) Schwann cells transplanted into the CNS. Int J Dev Neurosci 11:651-669. CrossRef Medline

Ramer LM, Au E, Richter MW, Liu J, Tetzlaff W, Roskams AJ (2004) Peripheral olfactory ensheathing cells reduce scar and cavity formation and promote regeneration after spinal cord injury. J Comp Neurol 473:1-15. CrossRef Medline

Ramón-Cueto A, Nieto-Sampedro M (1994) Regeneration into the spinal cord of transected dorsal root axons is promoted by ensheathing glia transplants. Exp Neurol 127:232-244. CrossRef Medline

Ramón-Cueto A, Plant GW, Avila J, Bunge MB (1998) Long-distance axonal regeneration in the transected adult rat spinal cord is promoted by olfactory ensheathing glia transplants. J Neurosci 18:3803-3815. Medline

Richter MW, Fletcher PA, Liu J, Tetzlaff W, Roskams AJ (2005) Lamina propria and olfactory bulb ensheathing cells exhibit differential integration and migration and promote differential axon sprouting in the lesioned spinal cord. J Neurosci 25:10700-10711. CrossRef Medline

Robinson S, Tani M, Strieter RM, Ransohoff RM, Miller RH (1998) The chemokine growth-regulated oncogene-alpha promotes spinal cord. oligodendrocyte precursor proliferation. J Neurosci 18:10457-10463. Medline

Saberi H, Firouzi M, Habibi Z, Moshayedi P, Aghayan HR, Arjmand B, Hosseini K, Razavi HE, Yekaninejad MS (2011) Safety of intramedullary Schwann cell transplantation for postrehabilitation spinal cord injuries: 2-year follow-up of 33 cases. J Neurosurg Spine 15:515-525. CrossRef Medline

Sabo JK, Aumann TD, Merlo D, Kilpatrick TJ, Cate HS (2011) Remyelina- 
tion is altered by bone morphogenic protein signaling in demyelinated lesions. J Neurosci 31:4504-4510. CrossRef Medline

Santos-Silva A, Fairless R, Frame MC, Montague P, Smith GM, Toft A, Riddell JS, Barnett SC (2007) FGF/heparin differentially regulates Schwann cell and olfactory ensheathing cell interactions with astrocytes: a role in astrocytosis. J Neurosci 27:7154-7167. CrossRef Medline

Sasaki M, Lankford KL, Zemedkun M, Kocsis JD (2004) Identified olfactory ensheathing cells transplanted into the transected dorsal funiculus bridge the lesion and form myelin. J Neurosci 24:8485-8493. CrossRef Medline

Schwab JM, Postler E, Nguyen TD, Mittelbronn M, Meyermann R, Schluesener HJ (2000) Connective tissue growth factor is expressed by a subset of reactive astrocytes in human cerebral infarction. Neuropathol Appl Neurobiol 26:434-440. CrossRef Medline

See J, Zhang X, Eraydin N, Mun SB, Mamontov P, Golden JA, Grinspan JB (2004) Oligodendrocyte maturation is inhibited by bone morphogenetic protein. Mol Cell Neurosci 26:481-492. CrossRef Medline

Silver J, Miller JH (2004) Regeneration beyond the glial scar. Nat Rev Neurosci 5:146-156. CrossRef Medline

Sims TJ, Gilmore SA (1983) Interactions between intraspinal Schwann cells and the cellular constituents normally occurring in the spinal cord: an ultrastructural study in the irradiated rat. Brain Res 276:17-30. CrossRef Medline

Sommer I, Schachner M (1981) Monoclonal antibodies (O1 to O4) to oligodendrocyte cell surfaces: an immunocytological study in the central nervous system. Dev Biol 83:311-327. CrossRef Medline

Sorensen A, Moffat K, Thomson C, Barnett SC (2008) Astrocytes, but not olfactory ensheathing cells or Schwann cells, promote myelination of CNS axons in vitro. Glia 56:750-763. CrossRef Medline

Spliet WG, Aronica E, Ramkema M, Aten J, Troost D (2003) Increased expression of connective tissue growth factor in amyotrophic lateral sclerosis human spinal cord. Acta Neuropathol 106:449-457. CrossRef Medline

Stankoff B, Aigrot MS, Noël F, Wattilliaux A, Zalc B, Lubetzki C (2002) Ciliary neurotrophic factor (CNTF) enhances myelin formation: a novel role for CNTF and CNTF-related molecules. J Neurosci 22:9221-9227. Medline

Stritt C, Stern S, Harting K, Manke T, Sinske D, Schwarz H, Vingron M, Nordheim A, Knöll B (2009) Paracrine control of oligodendrocyte dif- ferentiation by SRF-directed neuronal gene expression. Nat Neurosci 12: 418-427. CrossRef Medline

Toft A, Scott DT, Barnett SC, Riddell JS (2007) Electrophysiological evidence that olfactory cell transplants improve function after spinal cord injury. Brain 130:970-984. CrossRef Medline

Wang Y, Cheng X, He Q, Zheng Y, Kim DH, Whittemore SR, Cao QL (2011) Astrocytes from the contused spinal cord inhibit oligodendrocyte differentiation of adult oligodendrocyte precursor cells by increasing the expression of bone morphogenetic proteins. J Neurosci 31:6053-6058. CrossRef Medline

Woodhoo A, Sahni V, Gilson J, Setzu A, Franklin RJ, Blakemore WF, Mirsky R, Jessen KR (2007) Schwann cell precursors: a favourable cell for myelin repair in the central nervous system. Brain 130:2175-2185. CrossRef Medline

Yamamura T, Konola JT, Wekerle H, Lees MB (1991) Monoclonal antibodies against myelin proteolipid protein: identification and characterization of two major determinants. J Neurochem 57:1671-1680. CrossRef Medline

Ye P, Carson J, D’Ercole AJ (1995) Insulin-like growth factor-I influences the initiation of myelination: studies of the anterior commissure of transgenic mice. Neurosc Lett 201:235-238. CrossRef Medline

Ye P, Li L, Richards RG, DiAugustine RP, D’Ercole AJ (2002) Myelination is altered in insulin-like growth factor-I null mutant mice. J Neurosci 22: 6041-6051. Medline

Yim SH, Sherin JE, Szuchet S (1993) Oligodendrocyte proteoglycans: modulation by cell-substratum adhesion. J Neurosci Res 34:401-413. CrossRef Medline

Zujovic V, Thibaud J, Bachelin C, Vidal M, Coulpier F, Charnay P, Topilko P, Baron-Van Evercooren A (2010) Boundary cap cells are highly competitive for CNS remyelination: fast migration and efficient differentiation in PNS and CNS myelin-forming cells. Stem Cells 28:470-479. CrossRef Medline

Zujovic V, Doucerain C, Hidalgo A, Bachelin C, Lachapelle F, Weissert R, Stadelmann C, Linington C, Baron-Van Evercooren A (2012) Exogenous Schwann cells migrate, remyelinate and promote clinical recovery in experimental auto-immune encephalomyelitis. PLoS One 7:e42667. CrossRef Medline 